\title{
Nutrient limitation of primary productivity in the Southeast Pacific (BIOSOPE cruise)
}

\author{
S. Bonnet ${ }^{1}$, C. Guieu ${ }^{1}$, F. Bruyant ${ }^{2}$, O. Prášil ${ }^{3}$, F. Van Wambeke ${ }^{4}$, P. Raimbault ${ }^{4}$, T. Moutin ${ }^{4}$, C. Grob ${ }^{1}$, \\ M. Y. Gorbunov ${ }^{5}$, J. P. Zehrr ${ }^{6}$, S. M. Masquelier ${ }^{7}$, L. Garczarek ${ }^{7}$, and H. Claustre ${ }^{1}$ \\ ${ }^{1}$ Laboratoire d'Océanographie de Villefranche, UMR 7093, CNRS and Université Pierre et Marie Curie, BP 0806238 \\ Villefranche sur mer Cedex, France \\ ${ }^{2}$ Dalhousie University-Department of Oceanography, 1355 Oxford Street Halifax, NS, B3H 4J1, Canada \\ ${ }^{3}$ Institute of Microbiology ASCR, Opatovický mlýn, 37981 Trebon and University of South Bohemia, Zámek, 37333 Nové \\ Hrady, Czech Republic \\ ${ }^{4}$ Centre d'Océanologie de Marseille - Campus de Luminy, 13288 Marseille Cedex 09, France \\ ${ }^{5}$ Rutgers University, Institute of marine and Costal Sciences, 71 Dudley road, New Brunswick, N. J. 08901-8521, USA \\ ${ }^{6}$ University of California Santa Cruz, Ocean Sciences Department, 1156 high street, Santa Cruz, CA 95064, USA \\ ${ }^{7}$ Station Biologique de Roscoff, UMR 7144, CNRS and Univ. Pierre et Marie Curie, BP 74, 29682 Roscoff Cedex, France
}

Received: 2 July 2007 - Published in Biogeosciences Discuss.: 9 August 2007

Revised: 19 November 2007 - Accepted: 11 January 2008 - Published: 20 February 2008

\begin{abstract}
Iron is an essential nutrient involved in a variety of biological processes in the ocean, including photosynthesis, respiration and dinitrogen fixation. Atmospheric deposition of aerosols is recognized as the main source of iron for the surface ocean. In high nutrient, low chlorophyll areas, it is now clearly established that iron limits phytoplankton productivity but its biogeochemical role in low nutrient, low chlorophyll environments has been poorly studied. We investigated this question in the unexplored southeast Pacific, arguably the most oligotrophic area of the global ocean. Situated far from any continental aerosol source, the atmospheric iron flux to this province is amongst the lowest of the world ocean. Here we report that, despite low dissolved iron concentrations $\left(\sim 0.1 \mathrm{nmoll}^{-1}\right)$ across the whole gyre ( 3 stations located in the center and at the western and the eastern edges), primary productivity are only limited by iron availability at the border of the gyre, but not in the center. The seasonal stability of the gyre has apparently allowed for the development of populations acclimated to these extreme oligotrophic conditions. Moreover, despite clear evidence of nitrogen limitation in the central gyre, we were unable to measure dinitrogen fixation in our experiments, even after iron and/or phosphate additions, and cyanobacterial nif $\mathrm{H}$ gene abundances were extremely low compared to the North Pacific Gyre. The South Pacific gyre is therefore unique with respect to the physiological status of its phytoplankton populations.
\end{abstract}

Correspondence to: S. Bonnet

(sbonnet@usc.edu)

\section{Introduction}

The production of organic matter in the sea is sustained by a continuous supply of essential macro- $(\mathrm{C}, \mathrm{N}, \mathrm{P})$ and micronutrients (metals, vitamins). The nutrients requirements vary among different phytoplanktonic species. According to the Liebig's law, organic matter production is controlled by the element that is available in the lowest concentration relative to the growth requirements. This simple view is now replaced by the realization that multiple resources simultaneously limit phytoplankton growth in some parts of the ocean (Arrigo, 2005). Global environmental forcings, including human-induced climate change, could potentially modify the nutrient delivery processes to the ocean, leading to fundamental changes in the diversity and functioning of the marine food web. It is thus fundamental to understand which nutrients control primary productivity in the open ocean to predict the biogeochemical consequences of global change. Representing $60 \%$ of the global ocean's area, the subtropical open-ocean ecosystems are the largest coherent biomes on our planet, and the biogeochemical processes they support are of global importance (Emerson et al., 1997; Karl, 2002). The development of permanent time series stations in the North tropical Atlantic and Pacific over the past two decades have led to a revolution in the understanding of the mechanisms and controls of nutrient dynamics in these remote environments. These oceanic gyres provide ideal ecological niche for the development of nitrogen-fixing organisms (e.g. Karl et al., 2002). In the North subtropical and tropical Atlantic and Pacific oceans, it has been estimated that dinitrogen fixation is equivalent to $50-180 \%$ of the flux

Published by Copernicus Publications on behalf of the European Geosciences Union. 
a

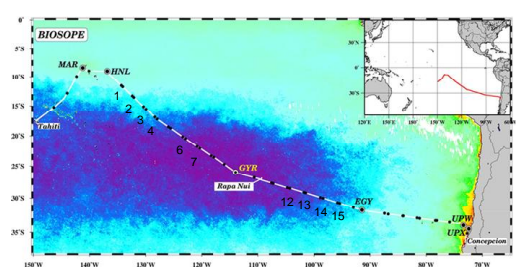

b

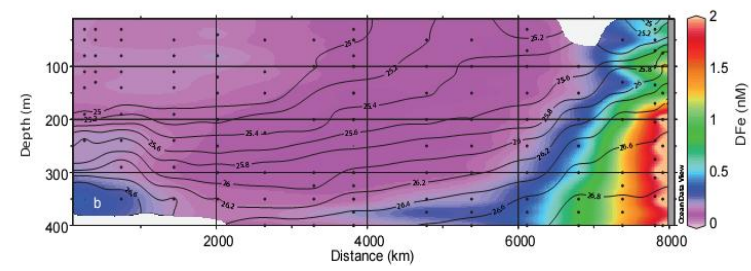

Fig. 1. (a) Transect of the BIOSOPE cruise from the Marquesas Islands to Chile superimposed on a SeaWiFS surface Chl- $a$ composite image (November-December 2004), and location of the short (numbers) and long-stations of the cruise (MAR, HNL, GYR, EGY, UPW, UPX). This study reports results of bioassay experiments performed at stations HNL, GYR and EGY. (b) Dissolved iron concentrations $(0-400 \mathrm{~m})\left(\mathrm{nmol}^{-1}\right)$ along the BIOSOPE transect from Marquesas Islands (left) to Chile (right).

of $\mathrm{NO}_{3}^{-}$into the euphotic zone (Karl et al., 1997; Capone et al., 2005), demonstrating that a large part of new primary productivity is fuelled by $\mathrm{N} 2$ fixation, rather than $\mathrm{NO}_{3}^{-}$diffusing from deeper layer into the euphotic zone. Dinitrogen fixation requires the iron-rich nitrogenase complex, therefore $\mathrm{N}_{2}$-fixing organisms have high iron $(\mathrm{Fe})$ requirements compared to phytoplankton growing on nitrate or ammonium (Raven, 1988; Kustka et al., 2003). Dinitrogen fixation in oceanic gyres has been seen to be controlled by $\mathrm{Fe}$ availability, as well as phosphate, which can (co)limit the process (Sanudo-Wilhelmy et al., 2001; Mills et al., 2004). However, all studies dedicated to the nutrient control of primary productivity and dinitrogen fixation have focused so far on the Northern Hemisphere and there are few data available in the Southern Hemisphere.

The South Pacific gyre, which is the largest oceanic gyre of the global ocean, had been particularly undersampled (Claustre et al. see introduction of this issue). This unique environment appears from satellite imagery and ocean colour to have the lowest chlorophyll- $a$ (Chl- $a$ ) concentrations of the global ocean and thus represents an end-member of oceanic hyperoligotrophic conditions (Claustre and Maritorena, 2003). In contrast to the oceanic gyres located in the Northern Hemisphere, the South Pacific Gyre is far removed from any continental source (anthropogenic and natural desert aerosols) and receives amongst the lowest atmospheric $\mathrm{Fe}$ flux in the world (Wagener et al., 2008). Consequently, the phytoplankton community as a whole, and particularly nitrogen-fixing organisms have been suggested to be Fe-limited (Falkowski et al., 1998; Berman-Frank et al., 2001; Moore et al., 2002), but direct experiment were lacking.

The BIOSOPE cruise provided the first spatially extensive experiment in the Southeast Pacific. We conducted nutrient addition bioassays, designed to investigate which nutrient ( $\mathrm{N}, \mathrm{P}$ and/or $\mathrm{Fe}$ ) controls primary productivity, photosynthetic efficiency and dinitrogen fixation along a trophic gradient in the Southeast Pacific. A complementary paper (Van Wambeke et al. this issue) examines the factors that control heterotrophic bacterial growth in the same area.

\section{Material and methods}

This research was carried out onboard the R/V Atalante in October-November 2004. The experiments were performed at three stations (Fig. 1a) located in the western edge (station $\mathrm{HNL}, 9^{\circ} \mathrm{S} 136^{\circ} \mathrm{W}$ ), in the center (station GYR, $26^{\circ} \mathrm{S}$ $114^{\circ} \mathrm{W}$ ) and in the southeastern edge of the gyre (station $\left.\mathrm{EGY}, 34^{\circ} \mathrm{S} 92^{\circ} \mathrm{W}\right)$.

All experimental setups were performed under strict trace metal clean conditions inside a clean container. Seawater was collected at $30 \mathrm{~m}$ depth using a trace metal-clean Teflon pump system and dispensed into 21 to 33 (depending on the number of treatments) acid-washed 4.51 transparent polycarbonate bottles. Under a laminar flow hood, nutrients or dust were added either alone or in combination: $+\mathrm{Fe},+\mathrm{NPSi}$ and $+\mathrm{FeNPSi}$ at station $\mathrm{HNL},+\mathrm{Fe},+\mathrm{N},+\mathrm{P},+\mathrm{FeN},+\mathrm{FeNP}$ and + dust at stations GYR and EGY. The final concentrations were $1 \mu \mathrm{moll}^{-1} \mathrm{NH}_{4}^{+}, 2 \mu \mathrm{moll}^{-1} \mathrm{NaNO}_{3}{ }^{-}, 0.3 \mu \mathrm{moll} l^{-1}$ $\mathrm{NaH}_{2} \mathrm{PO}_{4}, 2 \mathrm{nmol}^{-1} \mathrm{FeCl}_{3}$ and $0.25 \mathrm{mgl}^{-1}$ of dust. Despite the fact that Saharan dust deposition events are unlikely to occur in the Southeast Pacific, the dust used in this experiment was the Saharan soils collected and characterized by Guieu et al. (2002) in order to allow a comparison with earlier efforts (Mills et al., 2004; Blain et al., 2004, Bonnet et al., 2005). Each fertilization was performed in triplicate. The bottles were immediately capped with parafilm, sealed with PVC tape, and incubated for $48 \mathrm{~h}$ in an on-deck incubator with circulating surface seawater at appropriated irradiance (50\% ambient light level). For each station, the incubation started in the morning. After two selected time points during the course of the experiment $\left(\mathrm{T}_{1}=24 \mathrm{~h} ; \mathrm{T}_{2}=48 \mathrm{~h}\right)$, three replicates of each treatment were sacrificed in order to measure the following parameters: variable fluorescence, Chl- $a$ concentrations, epifluorescence microscopy counts and flow cytometry. For rate measurements such as primary productivity and dinitrogen fixation, subsamples of each 4.51 microcosms have been used after each time point ( $24 \mathrm{~h}$ and $48 \mathrm{~h}$ ) for parallel incubations (see below). For each parameter, treatment means were compared using a one-way ANOVA and a Fisher PLSD means comparison test. 


\subsection{Nutrient analysis}

Ambient nutrient concentrations have been measured at each of the three stations before the incubation experiments as well as during the incubations. Concentrations of nitrate, nitrite, phosphate and silicate have been analysed using a Technicon Autoanalyser II (Treguer and Le Corre, 1975). All the measurements have been done onboard, except for the silicate samples, which were poisoned (mercuric chloride $1 \mu \mathrm{g} \mathrm{ml}^{-1}$ ) and analyzed on land. Measurements in the nanomolar range (lower detection limit $=3$ nmoles $1^{-1}$ ) were obtained from the sensitive method described by Raimbault et al. (1990). Nitrate at submicromolar levels (detection limit: $0.05 \mu$ moles $1^{-1}$ ) and phosphate (detection limit: $0.02 \mu$ moles $1^{-1}$ ) were measured according to Armstrong et al. (1967). Ammonium concentrations were measured as described by Holmes et al.(1999), with a detection limit of 5 nmoles $1^{-1}$

\subsection{Dissolved iron (DFe) concentrations}

DFe concentrations were measured on 19 vertical profiles $(0-400 \mathrm{~m})$ along the $8000 \mathrm{~km}$ transect. They were analyzed by Flow Injection Analysis with online preconcentration and chemiluminescence detection (FIA-CL) (adapted from Obata et al., 1993). The mean blank, calculated from daily determinations, equaled $69 \pm 18 \mathrm{pmol}^{-1}(\mathrm{n}=19)$ and the detection limit was $54 \mathrm{pmol}^{-1}$. Each sample was analyzed in triplicate. When at least two of the three runs agreed within expected reproducibility $(10 \%)$, the average of the two or three concordant runs was taken as a correct concentration. If the concentration obtained deviated too much from the profile continuum expectations and seemed to be contaminated, one of the other sampled bottles was then analyzed (in triplicate) (see Blain et al. this issue, for more details on the methodology).

\subsection{Dinitrogen fixation}

At the last time point of each experiment, $0.6 \mathrm{ml}$ of each microcosms have been subsampled. $1 \mathrm{ml}$ of ${ }^{15} \mathrm{~N}_{2}$ gas $(99 \%$

${ }^{15} \mathrm{~N}_{2}$ EURISOTOP) was introduced to each 0.61 polycarbonate bottle through a Teflon-lined butyl rubber septum using a gas-tight syringe according to Montoya et al. (1996). After $24 \mathrm{~h}$ of incubation, the samples were filtered under low vacuum $(100 \mathrm{~mm} \mathrm{Hg})$ through a precombusted $\left(24 \mathrm{~h}\right.$ at $\left.450^{\circ} \mathrm{C}\right)$ $25-\mathrm{mm} \mathrm{GF} / \mathrm{F}$ filter and dried at $60^{\circ} \mathrm{C}$. Filters were stored in a desiccator until analysed. Determination of ${ }^{15} \mathrm{~N}$ enrichments was performed with an Integra-CN PDZ EUROPA mass spectrometer. The background natural abundance determined on 8 unlabelled samples was $0.367 \pm 0.007 \%$ for $\mathrm{N}$. Only excess enrichments larger than twice the standard deviation $(0.014 \%$ for $\mathrm{N})$ were considered as significant. The spectrometer was calibrated in order to detect the low levels of particulate nitrogen encountered; it was calibrated with glycin references every batch of 10-15 samples. The accuracy of our analytical system was also regularly verified using reference materials from the International Atomic Energy Agency (AIEA, Analytical Quality Control Services). Based on the lowest nitrogen level determined by our mass spectrometer $(0.2 \mu$ moles $)$, the detection limit for dinitrogen fixation was $0.3 \mu$ moles $1^{-1}$. Dinitrogen fixation rates $(\mathrm{rN}$ in nmoles $\mathrm{N}^{-1} \mathrm{t}^{-1}$ ) were computed from an equation based on final particulate nitrogen (Dugdale and Wilkerson, 1986) (see Raimbault and Garcia, this issue for more details on the methodology).

\subsection{Primary productivity}

After each time point, primary production was measured on $250 \mathrm{ml}$ subsamples of each microcosm as described by Moutin and Raimbault (2002). Each subsample was inoculated with $0.37 \mathrm{MBq}$ of $\mathrm{NaH}^{14} \mathrm{CO}_{3}$ (Amersham CFA3) and incubated in a on-deck incubator (50\% ambient light level) for four to seven hours around noon. Three samples were filtered immediately after inoculation for radioactivity determination at T0, and $250 \mu \mathrm{l}$ were sampled randomly from three bottles and stored with $250 \mu \mathrm{l}$ of ethanolamine to determine the quantity of added tracer $\left(Q_{i}\right)$. After incubation, the samples were filtered on GF/F filters, covered with $500 \mu \mathrm{l}$ of $\mathrm{HCl}$ $0.5 \mathrm{~mol}^{-1}$ and stored for pending analysis in the laboratory. In the laboratory, samples were dried for $12 \mathrm{~h}$ at $60^{\circ} \mathrm{C}, 10 \mathrm{ml}$ of ULTIMAGOLD-MV (Packard) were added to the filters and the radioactivity measured after $24 \mathrm{~h}$ with a Packard Tri carb 2100 TR liquid scintillation analyser. The hourly rate of primary production (PP) was calculated as:

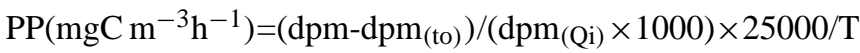
with $\mathrm{T}=$ incubation duration.

\subsection{Flow cytometry}

Cytometric analyses for picophytoplankton were performed on fresh samples with a FACSCalibur (Becton Dickinson) flow cytometer. Populations were differentiated based on their scattering and fluorescence signals (Marie et al., 2000). Samples were acquired for 3 minutes at $\sim 80 \mu \mathrm{l}$ $\min ^{-1}$ ( $\sim 12$ to $100 \times 10^{3}$ cells) using Cell Quest Pro software and data were analysed using the Cytowin software (see http://www.sb-roscoff.fr/Phyto/index.php?option=com docman $\backslash \&$ task=cat_view\&gid=118 $\backslash \&$ Itemid=112). Forward scatter (FSC) and chlorophyll- $a$ fluorescence (FL3) cytometric signals were normalized to reference beads (Fluoresbrite ${ }^{\circledR}$ YG Microspheres, Calibration Grade $1.00 \mu \mathrm{m}$, Polysciences, Inc) and then used as indicators of mean cell size and intracellular chlorophyll content, respectively (e.g. Campbell and Vaulot 1993). Significant changes in mean FSC and FL3 after incubation under the different treatments (48 h) was evaluated through ANOVA analyses. 


\subsection{Epifluorescence microscopy counts}

Counts were performed with a Olympus BX51 epifluorescence microscope. Water samples $(100 \mathrm{ml})$ were fixed with glutaraldehyde $(0.25 \%$ final concentration) and filtered through $0.8 \mu \mathrm{m}$ pore size filters. Samples were stained with 4'6-diamidino-2-phenylindole (DAPI, $5 \mu \mathrm{g} \mathrm{ml}^{-1}$ final concentration). Eukaryotes were identified and counted by standard epifluorescence microscopy (Porter and Feig, 1980).

\subsection{Variable fluorescence}

Chlorophyll variable fluorescence of phytoplankton was measured using the custom-built benchtop Fluorescence Induction and Relaxation (FIRe) system (Gorbunov and Falkowski, 2005). The excitation light was provided by 4 blue light-emitting diodes, LEDs, (central wavelength $450 \mathrm{~nm}, 30 \mathrm{~nm}$ bandwidth, with the peak optical power density of $2 \mathrm{~W} \mathrm{~cm}^{-2}$ ). The variable fluorescence sequences were processed to calculate minimum $\left(F_{o}\right)$ and maximum $\left(F_{m}\right)$ fluorescence (measured in the dark), as the quantum efficiency of PSII $\left(F_{v} / F_{m}\right)$, according to Kolber et al. (1998). Measurements were made on dark-adapted samples (30 min). The background fluorescence signal (blank) was measured using $0.2 \mu \mathrm{m}$ filtered seawater and was subtracted from the measured variable fluorescence.

\subsection{Abundance of nitrogen fixers}

Water samples ( 31 ) were filtered through $3 \mu \mathrm{m}$ pore size filters (GE Osmonics) and subsequently through $0.2 \mu \mathrm{m}$ pore size Supor filters (PALL corp.). Both filters were processed to determine the $\mathrm{N}_{2}$-fixing microorganisms in the $>3 \mu \mathrm{m}$ and $<3 \mu \mathrm{m}$ size fractions. DNA was extracted from the filters (Church et al., 2005) with the addition of a beadbeating step prior to the lysis step. The nif $\mathrm{H}$ gene was amplified with nested PCR primers (nif $\mathrm{H} 1$, nif $\mathrm{H} 2$, nif $\mathrm{H} 3$ and nif H4) (Church et al., 2005). The amplification products were cloned into pGEM®-T vectors (Promega). Plasmid DNA was isolated with Montage kits (Millipore) and the cloned inserts were sequenced at the University of California-Berkeley Sequencing facility. Quantitative PCR for Group A and B unicellular cyanobacterial nif $\mathrm{H}$ was performed as described in Church et al. (2005).

\subsection{Determination of pigments}

2.81 of seawater were filtered onto GF/F filters and immediately stored in liquid nitrogen then at $-80^{\circ} \mathrm{C}$ until analysis on land which was performed according to the procedure described in Ras et al. (2007). Pigment grouping into pigment-base size classes was performed according to Uitz et al. (2006).

\section{Results}

3.1 Initial nutrient concentrations and phytoplankton composition

The initial nutrient concentrations and phytoplanktonic species composition for these bioassay experiments are given in Table 1. Fe vertical profiles indicated low (below $0.134 \pm 0.05 \mathrm{nmoll}^{-1}$ ) and constant DFe concentrations from the surface to $400 \mathrm{~m}$ depth throughout the entire transect (station MAR throughout station EGY, $\mathrm{n}=110$ ), except in the Chilean coastal upwelling zone (Fig. 1b, see also Blain et al. this issue). Surface DFe concentrations were $0.14 \pm 0.02 \mathrm{nmoll}^{-1}$, $0.10 \pm 0.01 \mathrm{nmoll}^{-1}$ and $0.10 \pm 0.01 \mathrm{nmol} \mathrm{l}^{-1}$, respectively for the HNL, GYR and EGY stations (Table 1). In contrast, macronutrients and Chl- $a$ concentrations differed markedly among stations, with Chl- $a$ concentrations being $0.029 \pm 0.01 \mathrm{mg} \mathrm{m}^{-3}$ in $\mathrm{NO}_{3}^{-}$-depleted waters of GYR and $0.103 \pm 0.02$ and $0.110 \pm 0.01 \mathrm{mg} \mathrm{m}^{-3}$ respectively at EGY and $\mathrm{HNL}$, where $\mathrm{NO}_{3}^{-}$concentrations were higher $\left(0.02 \pm 0.02\right.$ and $1.66 \pm 0.11 \mu \mathrm{moll}^{-1}$; Table 1$)$. Waters were phosphate-replete along the whole transect with concentrations always above $0.11 \mu \mathrm{moll}^{-1}$.

The phytoplankton community structure was dominated by picophytoplankton at the three stations, where it represented $58 \%, 49 \%$ and $47 \%$ of the total Chl- $a$ (Table 1), respectively at HNL, GYR and EGY. Cyanobacteria, mainly belonging to the Prochlorococcus genera, dominated picophytoplancton. Phytoplankton pigment distribution along the transect is described in Ras et al. (2007).

\subsection{Biological response during the incubation experiments}

For all the parameters measured in this experiments, the stimulation by nutrients was considered to be significant when the ANOVA comparison of distribution of triplicate treatments gave values of $p<0.05$. The significant responses (different from the control) are indicated by an asterisk on Fig. 2 .

\subsubsection{Photosynthetic quantum efficiency of photosystem II}

The western part of the gyre (station HNL) was characterized by low $F_{v} / F_{m}(0.16 \pm 0.01)$ at $\mathrm{T} 0$ (Table 1$)$, indicating an apparently low yield of photosynthesis. Iron was found to be the nutrient that controls photosynthetic efficiency at that station, as indicated by the increase of $65 \%$ of $F_{v} / F_{m}$ after an Fe addition $(p<0.05$; Fig. 2$)$. The station located at the eastern side of the gyre (station EGY) exhibited medium $F_{v} / F_{m}$ values at $\mathrm{T} 0(0.30 \pm 0.02)$ (Table 1$)$ that increased significantly $(p<0.05)$ after $\mathrm{Fe}$ addition, but in a lower proportion compared to station HNL (30\%; Fig. 2). In contrast, the center of the South Pacific Gyre was characterized by high $F_{v} / F_{m}$ at T0 $(0.51 \pm 0.03)$ (Table 1$)$. This value didnot increase after Fe, N, P or dust addition ( $p>0.05$, Fig. 2). The 


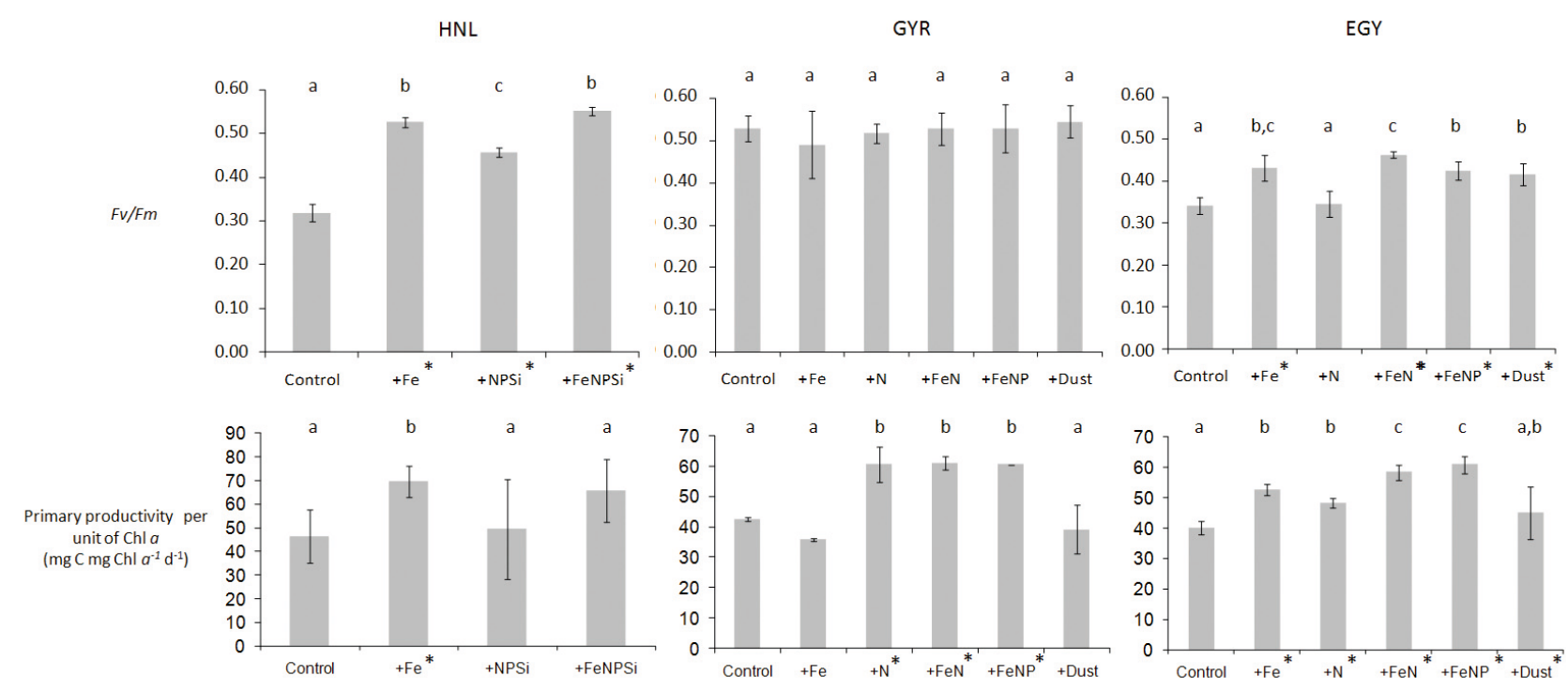

Fig. 2. Effect of nutrient additions during bioassay experiments performed at the three stations (HNL, GYR, EGY) (a) Photochemical

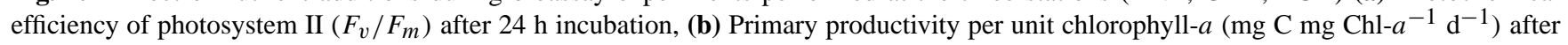
$48 \mathrm{~h}$ of incubation. $F_{v} / F_{m}$ and carbon fixation were measured from separate triplicate bottles, such that nine bottles were incubated for each nutrient treatment. The error bars represent the standard deviation from triplicate incubations. Treatment means were compared using a one-way ANOVA and a Fisher PLSD means comparison test. Means that are significantly different from the control are labelled with an asterisk and means that are not significantly different are labelled with the same letter $(p<0.05)$.

Table 1. Initial conditions for bioassay experiments. \% pico-, nano- and microphytoplankton correspond to the biomass proportion of total Chl- $a$ associated with each size class of phytoplankton calculated as described in Uitz et al. (2006).

\begin{tabular}{|c|c|c|c|}
\hline & Experiment $1 \mathrm{HNL}$ & Experiment 2 GYR & Experiment $3 \mathrm{EGY}$ \\
\hline Latitude Longitude & $9^{\circ} 04^{\prime} \mathrm{S} 136^{\circ} 97^{\prime} \mathrm{W}$ & $26^{\circ} 04^{\prime} \mathrm{S} 114^{\circ} 02^{\prime} \mathrm{W}$ & $31^{\circ} 89^{\prime} \mathrm{S} 91^{\circ} 39^{\prime} \mathrm{W}$ \\
\hline Chl- $a\left(\mathrm{mg} \mathrm{m}^{-3}\right)$ & $0.11 \pm 0.05$ & $0.029 \pm 0.01$ & $0.103 \pm 0.02$ \\
\hline $\mathrm{NO}_{3}^{-}\left(\mu \mathrm{moll}^{-1}\right)$ & $1.66 \pm 0.11$ & $<0.003$ & $0.02 \pm 0.02$ \\
\hline $\mathrm{NO}_{2}^{-}\left(\mu \mathrm{moll}^{-1}\right)$ & $0.03 \pm 0.00$ & $<0.003$ & $0.01 \pm 0.00$ \\
\hline $\mathrm{NH}_{4}^{+}\left(\mu \mathrm{moll}^{-1}\right)$ & $0.03 \pm 0.00$ & $0.006 \pm 0.00$ & $<0.005$ \\
\hline $\mathrm{PO}_{4}^{3-}\left(\mu \mathrm{moll}^{-1}\right)$ & $0.30 \pm 0.01$ & $0.11 \pm 0.02$ & $0.14 \pm 0.06$ \\
\hline $\mathrm{SiOH}_{4}\left(\mu \mathrm{moll}^{-1}\right)$ & $1.31 \pm 0.12$ & $0.98 \pm 0.09$ & $1.21 \pm 0.17$ \\
\hline $\mathrm{DFe}\left(\mathrm{nmol} 1^{-1}\right)$ & $0.14 \pm 0.02$ & $0.10 \pm 0.01$ & $0.10 \pm 0.01$ \\
\hline$F_{v} / F_{m}$ & $0.16 \pm 0.01$ & $0.51 \pm 0.03$ & $0.30 \pm 0.01$ \\
\hline$\%$ pico- & 58 & 49 & 47 \\
\hline$\%$ nano- & 31 & 48 & 43 \\
\hline$\%$ micro- & 11 & 13 & 10 \\
\hline
\end{tabular}

addition of macronutrients without $\mathrm{Fe}$ had a positive effect at station HNL, but did not have any effect at station EGY, where only a $\mathrm{Fe}$ addition (alone or in combination) resulted in an increase of $F_{v} / F_{m}$. The dust treatment also had a positive effect on $F_{v} / F_{m}$ at the station EGY.

\subsubsection{Rate measurements}

\section{Primary productivity}

At station HNL, only the addition of $\mathrm{Fe}$ resulted in a significant increase of primary productivity $(+50 \%$, $p<0.05$ ), whereas at station GYR, only the treatments having nitrogen $(+\mathrm{N},+\mathrm{FeN}$ and $+\mathrm{FeNP})$ resulted in a positive response $(+45 \%, p<0.05)$. At station EGY, all treatments 
Table 2. Abundance of diazotrophs (gene copies per liter) determined by QPCR for samples collected at 13 stations between HNL and EGY (ND: Non Detectable). The depth at which the nif $\mathrm{H}$ gene was detectable is indicated between parentheses. The nitrogen fixation rates (nmol $\mathrm{l}^{-1} \mathrm{~d}^{-1}$ ) measured at the three stations during the incubation experiments are also indicated. ${ }^{\text {a }}$ Data obtained from Church et al. (2005) at $25 \mathrm{~m}$ depth in December 2002 (Aloha station). ${ }^{\mathrm{b}}$ Data from Dore et al. (2002).

\begin{tabular}{|c|c|c|c|c|c|}
\hline & $<3 \mu \mathrm{m}$ & & $>3 \mu$ & & \\
\hline Station & Group A & Group B & Trichodesmium & Chaetoceros/Calothrix & $\mathrm{N}_{2}$ fixation rates \\
\hline HNL & $27(5 \mathrm{~m})$ & ND & ND & ND & \\
\hline 1 & ND & ND & ND & ND & \\
\hline 2 & ND & ND & ND & $30(70 \mathrm{~m})$ & ND \\
\hline 3 & ND & ND & ND & ND & \\
\hline 4 & ND & ND & ND & ND & \\
\hline 6 & - & ND & ND & ND & \\
\hline 7 & ND & ND & ND & ND & \\
\hline GYR & $184(5 \mathrm{~m})$ & ND & ND & ND & ND \\
\hline 12 & - & ND & ND & ND & \\
\hline 13 & ND & ND & ND & ND & \\
\hline 14 & ND & - & - & - & \\
\hline 15 & ND & ND & ND & ND & \\
\hline EGY & ND & ND & ND & ND & ND \\
\hline ALOHA & $10000-00000^{\mathrm{a}}$ & $1000^{\mathrm{a}}$ & $1000-10000^{\mathrm{a}}$ & - & $0.07-2.21^{b}$ \\
\hline
\end{tabular}

with a source of $\mathrm{Fe}$ or $\mathrm{N}$ resulted in a positive increase $(+25 \%)$. The addition of both $\mathrm{Fe}$ and $\mathrm{N}$ resulted in a higher response $(+50 \%)$, indicating a clear $\mathrm{Fe}$ and $\mathrm{N}$ co-limitation. At stations GYR and EGY, the addition of $\mathrm{P}$ together with $\mathrm{Fe}$ and $\mathrm{N}$ did not result in a significantly higher response than the addition of $\mathrm{Fe}$ and $\mathrm{N}$ alone, indicating that $\mathrm{P}$ is not limiting.

\section{Dinitrogen fixation}

${ }^{15} \mathrm{~N}_{2}$ assimilation consistently remained below the detection limit at the three stations in our incubation experiments (Table 2), indicating the absence of dinitrogen fixation, even after dust, Fe, and FeP additions.

\subsubsection{Abundance of nitrogen fixers}

Water samples from 13 stations situated between HNL and EGY (Fig. 1a) were examined for presence of $\mathrm{N}_{2}$-fixing microorganisms by amplification of the nif $\mathrm{H}$ gene. After amplification, cloning and sequencing the nitrogenase genes, our results indicate the absence of the filamentous cyanobacteria Trichodesmium, or any large (3-7 $\mu \mathrm{m})$ unicellular putative nitrogen fixing cyanobacteria (Group B). The results suggest however the presence of low numbers of Group A cyanobacterial phylotypes at two stations (less than 200 copies $1^{-1}$, Table 2), and low numbers of noncyanobacterial nif $\mathrm{H}$ sequences (Vibrio diazotrophicus and proteobacteria), that must explain the significant dinitrogen fixation rates measured by Raimbault et al. (2007) during the transect. It must be noted that the molecular data for both ends of the transect (data not related to these incubations) indicate the presence of larger number of cyanobacteria close to the Marquesas archipelago (up to 342 copies $1^{-1}$ Group B, 45 copies $1^{-1}$ Trichodesmium and 178 copies $1^{-1}$ Chaetoceros/Calothrix) and close to the Chilean upwelling (108 copies $1^{-1}$ Group B and 20 copies $1^{-1}$ Trichodesmium). These higher densities of diazotrophs are consistent with the higher dinitrogen fixation rates measured by Raimbault et al. (2007) at both ends of the transect.

\subsubsection{Cell numbers}

Epifluorescence microscopy confirmed the absence of the two phylotypes Trichodesmium and unicellular from Group $\mathrm{B}$ at any station and treatment, which is in agreement with molecular biology data. Concerning non nitrogen-fixing organisms, the addition of $\mathrm{Fe}$ or $\mathrm{Fe}$ and/or macronutrients at stations HNL resulted in a significant $(p<0.05)$ increase in Synechococcus and picoeukaryotes abundances (Table 3). At station EGY, all treatments containing nitrogen had a positive effect on picoeukaryotes, Prochlorococcus and Synechococcus abundances. At station GYR, only the $+\mathrm{N}$ and $+\mathrm{Fe}$ and $\mathrm{N}$ treatments induced a significant increase in picoeukaryotes abundances. The other treatments did not have any effect on this group, nor on Synechococcus. However, larger Synechococcus fluorescence (FL3) and forward light scatter (FSC) cytometric signals indicated at station GYR an increase in relative cell size and intracellular chlorophyll- $a$ content after addition of N, Fe and N and FeNP $(p<0.05$ for 
Table 3. Evolution of the abundances of Prochlorococcus, Synechococcus and picophyto-eukaryotes after $48 \mathrm{~h}$ of incubation at the three stations studied, for each treatment (cells ml ${ }^{-1}$; mean \pm SD). The standard deviation (SD) is calculated on the triplicates. At station GYR, Prochlorococcus fluorescence was too dim to allow us to detect changes in either the abundance or cytometric signals. Treatment means were compared using a one-way ANOVA and a Fisher PLSD means comparison test. Means that are significantly different from the control $(p<0.05)$ are labelled with an asterisk.

\begin{tabular}{|c|c|c|c|c|c|c|}
\hline \multicolumn{7}{|l|}{ HNL station } \\
\hline Sample & \multicolumn{2}{|c|}{ Prochlorococcus/ml } & \multicolumn{2}{|c|}{ Synechococcus/ml } & \multicolumn{2}{|c|}{ Picoeukaryotes/ml } \\
\hline Control & $264133 \pm$ & 17091 & $30096 \pm$ & 677 & $10140 \pm$ & 371 \\
\hline $\mathrm{Fe}$ & $116928 \pm$ & 1858 & $47740 \pm$ & $1256^{*}$ & $15502 \pm$ & $1039 *$ \\
\hline NPSi & $420368 \pm$ & $43935^{*}$ & $60892 \pm$ & $4157 *$ & $23309 \pm$ & $1056^{*}$ \\
\hline FeNPSi & $142137 \pm$ & 12420 & $61178 \pm$ & $1726^{*}$ & $18243 \pm$ & $1398 *$ \\
\hline \multicolumn{7}{|l|}{ GYR station } \\
\hline Sample & \multirow{2}{*}{\multicolumn{2}{|c|}{$\begin{array}{l}\text { Prochlorococcus/ml } \\
\text { nd }\end{array}$}} & \multicolumn{2}{|c|}{ Synechococcus/ml } & \multicolumn{2}{|c|}{ Picoeukaryotes/ml } \\
\hline Control & & & $1704 \pm$ & 272 & $572 \pm$ & 109 \\
\hline $\mathrm{Fe}$ & nd & & $1873 \pm$ & 176 & $518 \pm$ & 37 \\
\hline $\mathrm{N}$ & nd & & $1659 \pm$ & 119 & $775 \pm$ & $144^{*}$ \\
\hline $\mathrm{FeN}$ & nd & & $1491 \pm$ & 79 & $916 \pm$ & $106^{*}$ \\
\hline FeNP & no & & $1546 \pm$ & 55 & $678 \pm$ & 113 \\
\hline Dust & nd & & $2012 \pm$ & 129 & $625 \pm$ & 33 \\
\hline \multicolumn{7}{|l|}{ EGY station } \\
\hline Sample & \multicolumn{2}{|c|}{ Prochlorococcus/ml } & \multicolumn{2}{|c|}{ Synechococcus/ml } & \multicolumn{2}{|c|}{ Picoeukaryotes/ml } \\
\hline Control & $158798 \pm$ & 6284 & $18743 \pm$ & 512 & $6422 \pm$ & 162 \\
\hline $\mathrm{Fe}$ & $102588 \pm$ & 3761 & $15963 \pm$ & 795 & $5724 \pm$ & 141 \\
\hline $\mathrm{N}$ & $253317 \pm$ & $19927 *$ & $20521 \pm$ & $900 *$ & $8642 \pm$ & $589 *$ \\
\hline $\mathrm{FeN}$ & $129818 \pm$ & 12825 & $18129 \pm$ & 669 & $7960 \pm$ & $237 *$ \\
\hline FeNP & $127752 \pm$ & 7424 & $17400 \pm$ & 454 & $8694 \pm$ & $186^{*}$ \\
\hline Dust & $138278 \pm$ & nd & $17936 \pm$ & 481 & $8288 \pm$ & $312 *$ \\
\hline
\end{tabular}

Table 4. Cytometric signals obtained at station GYR for each treatment. Significant changes in mean FSC and FL3 after incubation under the different treatments $(48 \mathrm{~h})$ was evaluated using a oneway ANOVA. Significant data $(p<0.05)$ are labelled with an asterisk. Abbreviations: Proc (Prochlorococcus), Syn (Synechococcus), Euk (picophytoeukaryotes), SSC (side scattered light intensity), FSC (Forward scattered light intensity), FL3 (chlorophyll- $a$ fluorescence).

\begin{tabular}{llllll}
\hline & $\mathrm{Fe}$ & $\mathrm{N}$ & $\mathrm{Fe}$ and N & All & Dust \\
\hline SSC Proc. & $0.065^{*}$ & $0.013^{*}$ & $0.024^{*}$ & $0.034^{*}$ & $0.016^{*}$ \\
FSC Syn. & 0.470 & $0.012^{*}$ & $0.006^{*}$ & $0.009^{*}$ & 0.858 \\
SSC Syn. & 0.792 & 0.805 & 0.374 & 0.444 & 0.400 \\
FL3 Syn. & 0.230 & $0.021^{*}$ & $0.020^{*}$ & $0.018^{*}$ & 0.708 \\
FSC Euk. & 0.646 & $0.011^{*}$ & 0.259 & 0.221 & 0.883 \\
SSC Euk. & 0.663 & $0.002^{*}$ & 0.124 & $0.048^{*}$ & 1.000 \\
FL3 Euk. & 0.096 & $0.032^{*}$ & 0.117 & $0.01^{*}$ & 0.595 \\
\hline
\end{tabular}

FSC and FL3, Table 4). The presence of cyanobacteria in the size range 1 to $3 \mu \mathrm{m}$ was later confirmed by epifluorescence microscopy counts.

\section{Discussion}

\subsection{The role of $\mathrm{Fe}$}

The data indicate that $\mathrm{Fe}$ is the nutrient that controls photosynthetic efficiency and primary productivity outside the gyre, at station HNL. These results are in accordance with the patterns found in other HNLC waters (e.g. Boyd et al., 2000). Around Marquesas, Behrenfeld and Kolber (1999) also found low values of $F_{v} / F_{m}$ with a pronounced decrease at night; in our experiments, the addition of $\mathrm{Fe}$ eliminated the nocturnal decrease and increased $F_{v} / F_{m}$ values. In the central gyre (GYR), the high $F_{v} / F_{m}$ value $(0.51 \pm 0.03)$ was however unexpected due to the low dissolved Fe concentrations. This value is close to the maximum value observed in the ocean (Falkowski et al., 2004) and did not increase after Fe or dust addition. Behrenfeld et al. (2006) found the same pattern (high $F_{v} / F_{m}$, absence of nocturnal decrease) in the North Tropical Pacific, but the ambient dissolved Fe concentrations there are two to seven times higher (Boyle et al., 2005) than in the South Pacific Gyre, where our experiments were carried out. Our data also indicate that the addition of Fe did not change Chl- $a$ concentrations or primary productivity $(p>0.05)$, indicating that, in contrary to the HNL sta- 
tion, the photoautotrophic community was not Fe-limited in the gyre. This suggests that the natural assemblage is acclimated to Fe deprivation.

Flow cytometry measurements identified Prochlorococcus as a prominent component of the prokaryote-dominated phytoplankton assemblage at station GYR (20000 cells ml ${ }^{-1}$ ), whereas in terms of carbon biomass, picophytoeukaryotes dominated $\left(0.89 \mathrm{mg} \mathrm{C} \mathrm{m}^{-3}\right.$, i.e. 2.6-fold higher than Prochlorococcus). Although Synechococcus abundance was similar to that of Prochlorococcus $\left(1400\right.$ cells ml $\left.{ }^{-1}\right)$, their contribution to the phytoplanktonic carbon biomass was negligible $\left(0.06 \mathrm{mg} \mathrm{C} \mathrm{m}^{-3}\right)$. To maintain high carbon fixation rates in such a low $\mathrm{Fe}$ environment, the organisms must have developed ecophysiological strategies to survive the shortage of Fe, including Fe scavenging systems (Geider and la Roche, 1994), efficient $\mathrm{Fe}$ transport systems over the plasma membrane (Katoh et al., 2001) or gene regulation systems consisting in rearrangements of photosynthetic apparatus (Sandström et al., 2002).

In summary, although DFe concentrations were identical at the three stations, our data clearly show contrasting physiological responses to $\mathrm{Fe}$ additions. Cultures experiments conducted under $\mathrm{Fe}$ limited conditions exhibit either low $(\sim 0.1)$ or high $(\sim 0.5) F_{v} / F_{m}$ depending on whether growth is balanced or unbalanced (Price, 2005). The high $F_{v} / F_{m}$ values measured in the center of the gyre (GYR) are a clear indication that the phytoplankton assemblages are well acclimated to the stable environmental conditions of low $\mathrm{N}$ and low Fe. In contrast, station HNL (situated in the southern limit of the equatorial upwelling and embedded in the westward flowing South Equatorial Current) and station EGY (corresponding to a transition zone between the salty Eastern South Pacific Central Waters and the waters influenced by fresher Subantarctic Surface Waters (Emery and Meincke, 1986) are less steady environments, with low $F_{v} / F_{m}$ values and increased $F_{o}$ possibly due to the presence of specific $\mathrm{Fe}$ stress pigment-protein complexes (Behrenfeld et al., 2006). This might also suggest an unbalanced growth (Parkhill et al., 2001) in environment with occasional spikes of nutrients.

It is interesting to note that a dust addition did not cause any increase of primary productivity at station EGY, while an iron addition resulted in a positive response. This absence of response can be interpreted by the fact that only $0.1 \%$ of the iron in the dust dissolved, which is ten times lower than the dissolution found with the same amount of the same dust in the Mediterranean waters by Bonnet and Guieu (2004). This difference can be interpreted by the difference in organic ligands concentrations between the Pacific and the Mediterranean waters (Bonnet, 2005).

\subsection{From Fe to nitrogen limitation}

Dissolved Fe concentrations were low and constant along the three stations studied, but the data clearly show a progression from Fe limitation in station HNL towards nitrogen limita- tion in station GYR. Station EGY, located on the southeastern edge of the gyre, is a transition station where primary productivity is $\mathrm{Fe}$ and $\mathrm{N}$ co-limited. In the center of the gyre (station GYR), nitrogen is the nutrient that controls primary productivity. The addition of a nitrogen source resulted in an increase in the abundance of picophytoeukaryotes and an increase in relative cell size and intracellular Chl- $a$ content of Synechococcus $(p<0.05)$. It is interesting to note that bacterial production is also directly enhanced after a nitrogen addition (by a factor of 9 after 48 h, see Van Wambeke et al. this issue).

Perhaps the most intriguing part of this study is the absence of dinitrogen fixation in our experiments, even after dust, $\mathrm{Fe}$ and/or P additions. These results suggest that neither $\mathrm{P}$ nor $\mathrm{Fe}$ limit dinitrogen fixation at $30 \mathrm{~m}$ depth. It must be noted that Raimbault and Garcia (2007) measured low dinitrogen fixation rates at $30 \mathrm{~m}$ in the central gyre (stations GYR), revealing the weakness of the process at this depth. However, these authors measured significant $\mathrm{N}_{2}$ fixation rates in subsurface waters $\left(\sim 1 \mathrm{nmoll}^{-1} \mathrm{~d}^{-1}\right)$, which is in accordance with the molecular data (Table 2) and recent modelling efforts (Deutsch et al. 2007). At the other stations located between stations HNL and EGY, diazotrophic heterotrophic bacteria detected by molecular tools must be responsible of the dinitrogen fixation rates measured at regular stations by Raimbault and Garcia (2007). It has to be noted that the density of diazotrophic cyanobacteria are extremely low compared to those of the North Pacific Gyre (ALOHA station in December, 10000 to 100000 copies $1^{-1}$ ). The absence of Trichodesmium and Group B phylotypes also contrasts with amplification from oligotrophic waters of the tropical North Pacific Ocean, where cyanobacterial nif $\mathrm{H}$ genes from these two groups are abundant, even during the winter season (see Table 2; Church et al., 2005). In this area, dinitrogen fixation rates are high throughout the water column (Dore et al., 2002) and provide a major source of newly fixed nitrogen to the euphotic zone, sustaining up to $50 \%$ of new primary production, and drives the system towards $\mathrm{P}$ - and/or Fe-limitation (Karl et al., 1997; Sohm et al. ${ }^{1}$ ). The scarcity of nitrogen fixing organisms in the South Pacific Gyre may be one of the origins of the relatively large phosphate concentrations (always above $0.11 \mu \mathrm{moll}^{-1}$; Moutin et al., 2007), as well as the $\mathrm{N}$ controlled status of the phytoplankton and bacterial communities. However, the other potential sources of nitrogen for the South Pacific Gyre are small and dinitrogen fixation may nonetheless represent the main source of new nitrogen in the system (Raimbault and Garcia, 2007): the vertical flux of $\mathrm{NO}_{3}^{-}$from below the thermocline is extremely low compared to other gyres (10 to 12 times lower than the one measured in the North Atlantic gyre; Capone

\footnotetext{
${ }^{1}$ Sohm, J., Krauk, J., Mahaffey, C., Capone, D. G.: Diagnostics of phosphorus stress in the cyanobacterium Trichodesmium reveal the northwest Atlantic is more severely $\mathrm{P}$ limited than the tropical Pacific, Limnol. Oceanogr., submitted, 2008.
} 
et al., 2005), and potential atmospheric deposition of nitrogen is almost absent according to the aerosols measurements performed in this area by Wagener et al. (2008).

\section{Conclusions}

This paper is an attempt to analyse which are the nutrients that control primary productivity in the Southeast Pacific. A gradient in the nutrient control of phytoplanktonic communities is described, from an Fe-controlled system (on the edge of the gyre) towards a nitrogen-controlled system (in the center of the gyre). By combining physiological data, rate processes measurements and molecular approaches, this unique nutritional status of the phytoplankton populations is described for the first time in the gyre. Autotrophic communities are indeed adapted to living under extremely low Fe levels; these results add a new perspective on life in extreme environments and give a new perspective to so-called HNLC areas of the world ocean. In addition, we show for the first time that nitrogen fixing cyanobacteria are scarce in the South Pacific Gyre. Due to the extremely low Fe-rich dust inputs at the surface waters of the gyre, these waters constitute a "low iron" environment (Blain et al. this issue). It is hypothesized that this region is not a favourable environment for common photoautotrophic nitrogen fixing organisms (e.g. Trichodesmium), as they have elevated Fe quotas relative to non-diazotrophic phytoplankton (Kustka et al., 2003). However, the factors controlling dinitrogen fixation are still poorly understood and further studies are needed to understand the distribution of these organisms and their biogeochemical impact in the ocean.

Acknowledgements. Dominique Tailliez and Claudie Bournot are warmly thanked for their efficient help in CTD rosette management and data processing. This is a contribution of the BIOSOPE project of the LEFE-CYBER program. This research was funded by the Centre National de la Recherche Scientifique (CNRS), the Institut des Sciences de l'Univers (INSU), the Centre National d'Études Spatiales (CNES), the European Space Agency (ESA), The National Aeronautics and Space Administration (NASA), the Academy of Sciences (AVCR) and the Ministry of Education (MSMT) of the Czech Republic, and the Natural Sciences and Engineering Research Council of Canada (NSERC).

Edited by: J.-P. Gattuso

\section{References}

Armstrong, F. A. J., Stearns, C. R., and Strickland, J. D. H.: The measurement of upwelling and subsequent biological processes by means of the Technicon AutoAnalyzer and associated equipment, Deep Sea Res., 14(3), 381-389, 1967.

Arrigo, K. R.: Marine micro-organisms and global nutrient cycles, Nature, 437(7057), 349-355, 2005.

Behrenfeld, M. J. and Kolber, Z. S.: Widespread iron limitation of phytoplankton in the South Pacific Ocean, Science, 238 840843, 1999.

Behrenfeld, M. J., Worthington, K., Sherell, R. M., et al.: Controls on tropical Pacific ocean productivity revealed through nutrient stress diagnostic, Nature 442, 1025-1028, 2006.

Berman-Frank, I., J., Cullen, J., Hareli, Y., et al.: Iron availability, cellular iron quotas, and nitrogen fixation in Trichodesmium, Limnol. Oceanogr., 46, 1249-1277, 2001.

Blain, S., Bonnet, S., and Guieu, C.: Dissolved iron distribution in the tropical and sub tropical Southeastern Pacific, Biogeosciences Discuss., 4, 2845-2875, 2007, http://www.biogeosciences-discuss.net/4/2845/2007/.

Bonnet, S. and Guieu, C.: Dissolution of atmospheric iron in seawater. Geophys. Res. Lett., 31, L03303, doi:10.1029/2003GL018423, 2004.

Bonnet S., Guieu C., Chiaverini J., et al.: Impact of atmospheric inputs on the autotrophic communities in a low nutrient low chlorophyll system, Limnol. Oceanogr., 50(6), 1810-1819, 2005.

Bonnet, S.: The role of atmospheric iron in oligotrophic environments. Ph.D. thesis, University Pierre et Marie Curie, Paris 6, 207 pp., 2005.

Boyd, P. W., Watson, A. J., Law, C. S., et al.: A mesoscale phytoplankton bloom in the polar Southern Ocean stimulated by iron fertilization, Nature, 407, 695-702, 2000.

Boyle, E., Bergquist, B. A., Kayser, R. A., and Mahowald, N.: Iron, manganese, and Lead at Hawaii Ocean Time-series station ALOHA: Temporal variability and an intermediate water hydrothermal plume, Geochim. Cosmochim. Act., 69, 933-952, 2005.

Campbell, L. and Vaulot, D.: Photosynthetic picoplankton community structure in the subtropical North Pacific Ocean near Hawaii (station ALOHA).Deep-Sea Res., 40, 2043-2060, 1993.

Capone, D. G., Burns, J. A., Montoya, J. P. et al.: New nitrogen input to the tropical North Atlantic Ocean by nitrogen fixation by the cyanobacterium, Trichodesmium spp., Global Biogeoch. Cy., 19, GB2024, doi:10.1029/2004GB002331, 2005.

Church, M. J., Jenkins, B. D., Karl, D. M., and Zehr, J. P.: Vertical distributions of nitrogen-fixing phylotypes at Stn ALOHA in the oligotrophic North Pacific Ocean. Aquat. Microb. Ecol., 38(1), 3-14, 2005.

Claustre, H. and Maritorena, S.: The many shades of ocean blue, Science, 302, 1514-1515, 2003.

Deutsch, C., Sarmiento, J. L., Sigman, D. M., et al.: Spatial coupling of nitrogen inputs and losses in the ocean, Nature, 445, 163-167, 2007.

Dore, J. E., Brum, J. R., Tupas, L. M., and Karl, D. M.: Seasonal and Interannual Variability in Sources of Nitrogen Supporting Export in the Oligotrophic Subtropical North Pacific Ocean. Limnol. Oceanogr, 47, 1595-1607, 2002.

Dugdale, R. C. and Wilkerson, F. P.: The use of $15 \mathrm{~N}$ to measure nitrogen uptake in eutrophic oceans, experimental conditions. Lim- 
nol. Oceanogr., 31 673-689, 1986.

Emerson, S., Quay, P., Karl, D., et al.: Experimental determination of the organic carbon flux from open-ocean surface waters, Nature, 389, 951-954, 1997.

Emery, W. J. and Meincke, J.: Global water masses: summary and review. Oceanol. Acta., 9, 383-391, 1986.

Falkowski, P. G., Katz, M. E., Knoll, A. H., et al.: The Evolution of Modern Eukaryotic Phytoplankton., Nature, 305, doi: 0.1126/science.1095964, 354-360, 2004.

Falkowski, P. G., Barber, R. T., and Smetacek, V.: Biogeochemical controls and feedbacks on primary production, Science, 281, 200-206, 1998.

Falkowski, P. G.: Evolution of the nitrogen cycle and its influence on the biological sequestration of $\mathrm{CO}_{2}$ in the Ocean, Nature, 387, 272-275, 1997.

Geider, J. G. and La Roche, J.: The role of iron in phytoplankton. photosynthesis, and the potential for iron-limitation of primary production in the sea. Photosynth. Res., 39, 275-301, 1994.

Guieu C., Loÿe-Pilot, M.-D., Ridame, C., and Thomas, C.: Chemical characterization of the Saharan dust end-member; some biological implications for the western Mediterranean, J. Geophys. Res, 107(D15),4258, doi:10.1029/2001JD000582, 2002.

Gorbunov, M. Y. and Falkowski, P. G.: Fluorescence Induction and Relaxation (FIRe) Technique and Instrumentation for Monitoring Photosynthetic Processes and Primary Production in Aquatic Ecosystems. Photosynthesis: Fundamental Aspects to Global Perspectives. A. v. d. E. a. D. Bruce, Allen Press: 1029-1031, 2005.

Holmes, M. R., Aminot, A., Kerouel, R., Hooker, B. A., and Peterson,J. B.: A simple and precise method for measuring ammonium in marine and freshwater ecosystems, Can.J.FishAquat. Sci., 56, 1801-1808, 1999.

Karl, D. M., Letelier, R., Tupas, L., et al.: The role of nitrogen fixation in biogeochemical cycling in the subtropical North Pacific Ocean, Nature, 388, 533-538, 1997.

Karl, D. M.: Nutrient dynamics in the deep blue sea, Trends Microbiol, 10, 410-418, 2002.

Karl, D., Michaels, A., Bergman, B., Capone, D., Carpenter, E., Letelier, R., Lipschultz, F., Paerl, H., Sigman, D., and Stal, L.: Dinitrogen Fixation in the World's Oceans, Biogeochem., 57, 47-98, 2002.

Katoh, H., Hagino, N., Grossman, A. R., and Ohawa, T.: Gens essential to iron transoport in the cyaniobacterium synechocystis sp. stain PCC 6803, J. Bacteriol., 183(9), 2779-2784, 2001.

Kolber, Z., Prasil, O., and Falkowski, P.: Measurements of variable chlorophyll fluorescence using fast repetition technique I. Defining methodology and experimental protocols, Biochim. Biophys. Acta., 1367, 88-106, 1998.

Kustka, A. B., Carpenter, E. J., Sañudo-Wilhelmy, S., and Sunda, W. G.: Iron requirements for $\mathrm{N} 2$ and $\mathrm{NH} 4+$ supported growth in cultures of Trichodesmium (IMS 101): comparison with nitrogen fixation rates and Fe: $\mathrm{C}$ ratios of field populations, Limnol. Oceanogr., 48, 1869-1884, 2003.

Marie, D., Partensky, F., Simon, N., et al.: Flow cytometry analysis of marine picoplankton. living colors: protocols in flow cytometry and cell sorting, D. S. Diamond RA, NewYork, SpringerVerlag, 421-454, 2000.

Mills, M. M., Ridame, C., Davey, M., et al.: Iron and phosphorus co-limit nitrogen fixation in the eastern tropical North Atlantic,
Nature, 429, 292-294, 2004.

Montoya, J. P., Voss, M., Kaehler, P., and Capone, D. G.: A simple, high precision tracer assay for dinitrogen fixation, App. Environ. Microb., 62, 986-993, 1996.

Moore, J. K., Doney, S. C., Glover, D. M., Fung, I. Y.: Iron cycling and nutrient-limitation patterns in surface waters of the World Ocean, Deep-Sea Research Part II-Topical Studies in Oceanography, 49, 463-507, 2002.

Moutin, T. and Raimbault, P.: Primary production, carbon export and nutrients availability in western and eastern Mediterranean Sea in early summer 1996, J. Marine Syst., 33-34, 273-288, 2002.

Moutin T., Karl, D. M., Duhamel, S., Rimmelin, P., Raimbault, P., Van Mooy, B. A. S., and Claustre, H.: Phosphate availability and the ultimate control of new nitrogen input by nitrogen fixation in the tropical Pacific Ocean, Biogeosciences Discuss., 4, 2407 2440, 2007, http://www.biogeosciences-discuss.net/4/2407/2007/.

Obata, H., Karatani, H., and Nakayama, E.: Automated determination of iron in seawater by chelating resin concentration and chemiluminescence detection, Anal. Chem., 5, 1524-1528, 1993.

Parkhill, J. P., Maillet, G., and Cullen, J. J.: Fluorescence-based maximal quantum yield for PSII as a diagnostic of nutrient stress, J. Phycol., 17, 517-529, 2001.

Price, N. M.:The elemental stoichiometry and composition of an iron-limited diatom. Limnol. Oceanogr., 50, 1159-1171, 2005.

Porter, K. G. and Feig, Y. S.: The use of DAPI for identifying and counting aquatic microflora, Limnol. Oceanogr., 25, 943-948, 1980.

Raimbault P., Slawyk G., Coste B., and Fry J.: Feasibility of using an automated colorimetric procedure for the determination of seawater nitrate in the 0 to $100 \mathrm{nmol}^{-1}$ range: examples from field and culture, Mar. Biol., 104, 347-351, 1990.

Raimbault, P. and Garcia, N.: Carbon and nitrogen uptake in the South Pacific Ocean: Evidence for efficient dinitrogen fixation and regenerated production leading to large accumulation of dissolved organic matter in nitrogen-depleted waters, Biogeosciences Discuss., 4, 3531-3579, 2007, http://www.biogeosciences-discuss.net/4/3531/2007/.

Ras J., Claustre, H., and Uitz, J.: Spatial variability of phytoplankton pigment distributions in the Subtropical South Pacific Ocean: comparison between in situ and predicted data, Biogeosciences Discuss., 4, 3409-3451, 2007, http://www.biogeosciences-discuss.net/4/3409/2007/.

Raven, J. A.: The iron and molybdenum use efficiencies of plant growth with different energy, carbon and nitrogen source, New Phytol., 109, 279-287, 1988.

Sandström, S., Ivanov, A. G., Park, Y., et al.: Iron stress responses in the cyanobacterium Synechococcus sp. PCC7942, Physiol. Plantarum, 116(2), 255-263, doi:10.1034/j.1399-3054, 2002.

Sañudo-Wihelmy, S. A., Kustka, A., B., Gobler, C. J., et al. : Phosphorus limitation of nitrogen fixation by Trichodesmium in the central Atlantic Ocean, Nature, 411, 66-69, 2001.

Tréguer P. and Le Corre P.: Manuel d'analyse des sels nutritifs dans l'eau de mer. Utilisation de l'AutoAnalyser II Technicon. 2nd ed., Univ. Bretagne Occidentale, Laboratoire de Chimie marine, Brest, France, 1-110, 1975.

Uitz, J., Claustre, H., Morel, A., and Hooker, S. B: Vertical distri- 
bution of phytoplankton communities in open ocean: an assessment based on surface chlorophyll, J. Geophys. Res-oceans, 111, C08005, doi:10.1029/2005JC003207, 2006.

Van Wambeke F., Bonnet S., Moutin T., Raimbault P., Alarçon G., and Guieu C.: Factors limiting heterotrophic prokaryotic production in the Southern Pacific Ocean, Biogeosciences Discuss., 4, 3799-3828, 2007,

http://www.biogeosciences-discuss.net/4/3799/2007/.

Wagener, T., Guieu, C., Losno, R., Bonnet, S., and Mahowald, N.: Revisiting Atmospheric dust export to the South Hemisphere Ocean, Global Biogeochemical Cycles, in press, doi:10.1029/2007GB002984, Decenber 2007.
Zehr, J. P., Waterbury, J. B., Turner, P. J., et al.: New nitrogenfixing unicellular cyanobacteria discovered in the North Pacific subtropical gyre, Nature, 412, 635-638, 2001. 